Index Copernicus Value: 71.58

ISSN (e)-2347-176x ISSN (p) 2455-0450

crossref DOI: https://dx.doi.org/10.18535/jmscr/v5i10.165

Journal Of Medical Science And Clinical Research

\title{
Epidemiological Study of Urolithiasis with Special Reference to Its Chemical Nature
}

\author{
Dr Khwaja Nasim Ahmad ${ }^{1}$, Dr Md. Abdur Rahman', Dr Md. Shadab ${ }^{3}$, \\ Dr Amjad Zia Mallik ${ }^{4}$, Dr Yasir Tajdar ${ }^{5}$, Dr Ameet Kumar ${ }^{6}$, Dr Nadia Hasin ${ }^{7}$ \\ ${ }^{1}$ Associate Professor, Department of Surgery, K.M.C, Katihar \\ ${ }^{2,5,6,7}$ Post graduate, Department of Surgery, K.M.C, Katihar \\ ${ }^{3}$ Assistant professor, Department of Surgery, K.M.C, Katihar \\ ${ }^{4}$ Professor, Department of Surgery, K.M.C, Katihar
}

\begin{abstract}
Epidemiological Study of Urolithiasis with special reference to its chemical nature. To find out the quality of urinary stone. The collected stones were sent to the Department of Biochemistry, K.M.C.H, Katihar. Qualitative biochemical analysis were performed to know the composition of the stones by H. Varley method. It was a prospective study. A total of 23 patients had been studied. The study period is of 1 year duration of which male - 14, female - 9 all were collected after intervention. Age group was from 8 years to 70 years. $73.91 \%$ of the case studied was renal calculi. $94.11 \%$ of all the renal calculi was unilateral. $21.73 \%$ of all the urolith was ureteric calculi and bladder stone was $8.69 \%$.
\end{abstract}

\section{Introduction}

Urinary stones have afflicted human kind since antiquity, with the earliest recorded example being bladder and kidney stones detected in Egyptian mummies dated to 4800 B.C. The incidence of urolithiasis is increasing gradually all over the world including Bengal region. Most accounts of urinary stone disease, both renal and bladder, majority were unaccompanied by observable anatomic or metabolic disorder hence idiopathic. Poor economic condition had been associated with idiopathic bladder stone, composed principally of calcium oxalate ammonium urate and uric acid (Broek et. al. 1981, Sutor et. al. 1974). Affluent, industrialised and developed countries were to face predominantly the problem of idiopathic calcium kidney stones (Letl 1934, Gherdi et. al.
1973, GU 1978). The role of socio-economic factor in idiopathic renal stone occurrence was mediated by dietary habit. Anderson (1972) and Robertson et. al. 1973 noted that the men in the higher socio-economic group were more prevalently suffering from the disease. Power et. al. (1989) also found that town with better socioeconomic conditions were the places with higher incidence of renal stone.

\section{Methods}

All the patients admitted with urolithiasis in the department of General Surgery Katihar Medical College, Katihar were evaluated by history, clinical examinations, routine \& special investigations, imaging techniques, stone were collected after interventions, i.e. open operations 
or when it passed spontaneously. The collected stones $(n=23)$ were sent to the Department of Biochemistry, K.M.C.H,Katihar. Qualitative biochemical analysis were performed to know the composition of the stones by H. Varley method.

\section{Results}

Table - 1 Age, Sex Distribution of Calcium Oxalate and Calcium Phosphate Urolith

\begin{tabular}{|c|c|c|c|c|}
\hline \multirow{3}{*}{ Age (years) } & \multicolumn{4}{|c|}{ Sex } \\
\hline & \multicolumn{2}{|c|}{ Male } & \multicolumn{2}{|c|}{ Female } \\
\hline & $\mathrm{CaOx}$ & $\mathrm{CaP}$ & $\mathrm{CaOx}$ & $\mathrm{CaP}$ \\
\hline $0-10$ & 1 RK (child) & $\mathrm{X}$ & $1 \mathrm{RK}+\mathrm{V}$ (child) & $\mathrm{X}$ \\
\hline $10-20$ & $1 \mathrm{LK}$ & 1 LK (stag horn) & $1 \mathrm{LU}$ & $\begin{array}{c}\text { 1 LK (child) } \\
\text { (stag horn) }\end{array}$ \\
\hline $20-30$ & $\mathrm{X}$ & $1 \mathrm{RK}$ & $\mathrm{X}$ & $1 \mathrm{RK} \& 1 \mathrm{LU}$ \\
\hline $30-40$ & $1 \mathrm{LK}$ & $1 \mathrm{RU}$ & $\mathrm{X}$ & $2 \mathrm{RK} \& 1 \mathrm{BU}$ \\
\hline $40-50$ & $\begin{array}{c}2 \text { RK \& } 2 \text { LK } \\
\text { (1 LK stag horn) }\end{array}$ & $1 \mathrm{RK} \& 1 \mathrm{LU}$ & $\mathrm{X}$ & $\mathrm{X}$ \\
\hline $50-60$ & $\mathrm{X}$ & $\mathrm{X}$ & $\mathrm{X}$ & $1 \mathrm{BK}$ \\
\hline $60-70$ & $1 \mathrm{~V}$ & $1 \mathrm{LK}$ & $X$ & $\mathrm{X}$ \\
\hline
\end{tabular}

Note :

RK - Right Kidney Stone, LK - Left Kidney Stone, RU - Right Ureteric Stone

LU - Left Ureteric Stone, BK - Both Kidney Stone, V - Bladder Stone

$\mathrm{CaOx}$ - Calcium Oxalate, $\mathrm{CaP}$ - Calcium Phosphate

Table - 2 Age, Nature of Stone, Sex and Site of Stone Distribution of Urolith

\begin{tabular}{|c|c|c|c|c|}
\hline \multirow[t]{2}{*}{ Age (years) } & \multicolumn{2}{|c|}{$\mathrm{CaOx}$} & \multicolumn{2}{|c|}{$\mathrm{CaP}$} \\
\hline & Male & Female & Male & Female \\
\hline $0-10$ & $\begin{array}{l}\mathrm{C} / \mathrm{RK} \\
(1 \mathrm{~K})\end{array}$ & $\begin{array}{c}\mathrm{C} / \mathrm{RK}+\mathrm{B} \\
(1 \mathrm{~K}+\mathrm{B})\end{array}$ & $\mathrm{X}$ & $\mathrm{X}$ \\
\hline $10-20$ & $\begin{array}{c}\text { LK } \\
(1 \mathrm{~K})\end{array}$ & $\begin{array}{l}\mathrm{LU} \\
(1 \mathrm{U})\end{array}$ & $\mathrm{X}$ & $\begin{array}{c}\text { C/LK (stag horn) } \\
(1 \mathrm{~K})\end{array}$ \\
\hline $20-30$ & $\begin{array}{l}\text { LK (stag horn) } \\
(1 \mathrm{~K})\end{array}$ & $\mathrm{X}$ & $\begin{array}{l}\mathrm{RK} \\
(1 \mathrm{~K})\end{array}$ & $\begin{array}{c}\mathrm{RK}+\mathrm{LU} \\
2(1 \mathrm{~K}+1 \mathrm{U})\end{array}$ \\
\hline $30-40$ & $\begin{array}{l}\mathrm{LK} \\
(1 \mathrm{~K})\end{array}$ & $\mathrm{X}$ & $\begin{array}{l}\text { RU } \\
(1 U)\end{array}$ & $\begin{array}{c}\mathrm{LK}+\mathrm{R} \& \mathrm{LU}+\mathrm{RK} \\
3(2 \mathrm{~K}, 1 \mathrm{U})\end{array}$ \\
\hline $40-50$ & $\begin{array}{c}\text { RK + RK Rec. + LK } \\
(\text { stag horn + LK) } \\
(4 \mathrm{~K})\end{array}$ & $\mathrm{X}$ & $\begin{array}{c}\mathrm{LU}+\mathrm{RK} \\
2(1 \mathrm{~K}, 1 \mathrm{U})\end{array}$ & $X$ \\
\hline $50-60$ & $\mathrm{X}$ & $\mathrm{X}$ & $\mathrm{X}$ & R\&LK \\
\hline $60-70$ & $\begin{array}{c}\mathrm{B} \\
(1 \mathrm{~B})\end{array}$ & $\mathrm{X}$ & $\begin{array}{c}\text { LK } \\
(1 \mathrm{~K})\end{array}$ & $X$ \\
\hline
\end{tabular}

Note :

C - Child, R K - Right Kidney Stone, LK - Left Kidney Stone, LU - Left Ureteric Stone RU - Right Ureteric Stone, B - Bladder Stone

\section{Discussion \& Conclusion}

Present study was conducted in the Department of Surgery and Department of Biochemistry, K.M.C., Katihar. Total number of cases were 23 adult male -13 , adult female -7 , male child -1 and female child -2 . Age group was from 8 years to 70 years. Total number of renal stone were 17 , 16 cases unilateral and one bilateral. Among unilateral renal stones right:left sided ratio was 1:1, male:female ratio of renal stone was 11:6.
Male child:female child ration was 1:2 and adult male:female ratio was 5:2 for unilateral cases.

Bilateral renal stone was seen in one female, associated with bladder stone.

One male patient was suffering from recurrent right renal stone.

Ureteric stones were 5 - 2 males and 3 females. One female case was of bilateral involvement. Two bladder stones were found. One female child was associated with right sided renal stone. 
Stones were collected after interventions (pyelolithotomy, ureterolithotomy, cystolithotomy), and retrieved stones were sent to laboratory for chemical analysis in each case. Calcium oxalate was found in $47.83 \%$ cases and calcium phosphate in $52.17 \%$ cases. Among male patients, 8 cases were found with calcium oxalate and 5 cases with calcium phosphate In cases of female, calcium oxalate was found in 1 case and calcium phosphate in 6 cases. In children, one male patient suffered from calcium oxalate stone, 1 female from calcium oxalate and other one from calcium phosphate.

Incidence of idiopathic calcium stone disease is increasing. Male suffers more than their female counter part. Change in life style and food habit probably is incriminated for rise in stone disease. Also, genetic influences are important. It is a multi-factorial disease, chemical nature of stones influence the treatment procedure.

\section{References}

1. Monti E, Trinchieri A, Magri V, et. al.: Herbal medicines for urinary stone treatments. A systemic rerview. Arch Ital Urol Androl. 2016: 88 (1): 38-46.

2. Scott Kreigshauser J, Naidu SG, Paden RG, He M, Wu Q, Hara AK.Feasibility of ultra- low radiation dose dreuctionh for renal stone CT using model based iterative reconstruction: Prospective pilot study. Clin Imaghing 2015:39:99-103.

3. Huang GO, Engebretsen SR, Smith JC, Wallner CL, Culpepper DJ, Creech JD, et al.. Detection of uric acid stones in the ureter using low- and concentional dose CT. Urology 2014; 84:571-4.

4. Green W, Ratan H: Molecular Mechanism of urolitiasis. Urology 2013; 81(4): 701-4

5. Kulkarni NM, Uppot RN, Eisner BH, Sahni DV, Radiation Dose Reduction At Multidetector CT with Adaptive statistical iterative reconstruction for evaluation of urolithiasis: How low can we go? Radiology 2012; 265:158-66.

6. Eisner BH, McQuid JW, Hymes E, Matlaga BR. Nephrolithiasis: What surgeons need to know? AJR Am J Roentgenol 2011; 196:1274-8.

7. Hsu TC, Chen J. Huang HS. Wang CJ. : Association of changes in the pattern of urinary calculi in Taiwanese with diet habit change between 1956 \& 1999. Journal of the Formosan Medical Association. 101(1):5-10 2000Jan.

8. Decoster M. Bigot JC. Carre JL. Morin JF, Mahe JL. Tanguerel T . Cledes J, Floch HH. : Epidemiologic study of urinary calculi in western France. Press Medicale 31(3):113-9 2002Jan 26.

9. Sagara Y, Hara AK, Pavlicek W, Silva AC, Paden RG, Wu Q. Abdominal CT : Comparision of low dose $\mathrm{CT}$ with adaptive statistical iterative reconstruction and routine- dose CT with filtered back projection in 53 patients.AJR Am J Roentgenol 2010;195:713.

10. Safranow K: [Identification and quantitation of purine derivatives in urinary calculi as markers of abnormal purine metabolism by using highperformance liquid chromatography

11. Varley's Practical Clinical Biochemistry $6^{\text {th }}$ edition page $758-760$.

12. CAMPBELL'S UROLOGY $8^{\text {th }}$ Edition, volume-4. 